\title{
CURRENT TECHNIQUES FOR LASER PROSTATECTOMY-PVP AND HOLEP
}

\author{
Tevita F. Aho and Peter J. Gilling?.
}

Department of Urology. Addenbrooke's Hospital. Cambridge. UK. 'Department of Urology. Tauranga Hospital. New Zealand.

\begin{abstract}
Summary.- OBJECTIVES: The objective of this review is to provide an evidence-based update on laser surgery for $\mathrm{BPH}$ with a focus on comparing Greenlight Photoselective Vaporisation of the Prostate (PVP) to Holmium Laser Enucleation of the Prostate (HolEP).
\end{abstract}

METHODS: We reviewed all HoLEP and PVP papers identified by a Pubmed search using the keywords: laser, prostate, $B P H$, holmium, HoLEP, PVP and greenlight. The published randomised trials investigating HoLEP and PVP are summarised. As there are no head to head randomised trials comparing HolEP to PVP, we compare data from individual HolEP and PVP papers. Data on multiple aspects of laser surgery for $B P H$ are summarised and contrasted for the 2 procedures including: Perioperative management, subjective and objective measures of success, complications, sexual function, prostate volume re- duction, durability, and surgery for men with large prostates and those in urinary retention.

RESULTS/CONCLUSIONS: PVP and HoLEP are very different laser techniques. An important difference between the Greenlight laser and holmium and thulium is that its only urological application is prostate ablation. HoLEP is the most advanced laser technique currently available. In contrast to PVP, it has been rigorously evaluated in 8 randomised trials. It is a size independent procedure suitable for any prostate, and highly effective at treating urinary retention. HoLEP has been reported to be durable to periods up to 6 years. More tissue is removed with HoLEP than PVP, and this raises concerns regarding the long term durability of PVP for which there is no comparable data. The increase in HoLEP expertise world-wide and the development of lasers that are faster at ablating tissue and have other urological uses (eg thulium) may threaten the longevity of Greenlight PVP.

Keywords: Laser prostatectomy. Photoselective. Vaporisation. Prostate. PVP. Holep. Laser.

Resumen.- OBJETIVO: El objetivo de ésta revisión es ofrecer una puesta al día basada en la evidencia sobre cirugía láser para el tratamiento de la HBP, enfocada a la comparación entre vaporización fotoselectiva con láser verde (PVP) y la enucleación prostática con láser de Holmio(HoLEP).

MÉTODOS: Revisamos todos los artículos sobre HoLEP y PVP identificados en una búsqueda bibliográfica en PubMed utilizando los términos: láser, próstata, HBP, Holmio, HoLEP, PVP, y luz verde. Como no existen ensayos clínicos aleatorizados comparando directamente HoLEP y PVP comparamos los datos de artículos individuales de cada técnica. Se resumen y contrastan los datos de múltiples aspectos de la cirugía láser de la HBP mediante ambos procedimientos incluyendo: manejo perioperatorio, medidas objetivas y subjetivas de éxito, complicaciones, función sexual, reducción del volumen prostático, durabilidad y cirugía en varones con próstatas grandes y pacientes con retención urinaria. 
RESULTADOS/CONCLUSIONES: La PVP y la HoLEP son técnicas láser muy diferentes. Una diferencia importante entre el láser de luz verde y los de Holmio o Tulio es que su única aplicación es la ablación prostática. La técnica de enucleación con láser de Holmio es la técnica láser más avanzada disponible actualmente. En contraste con la fotovaporización ha sido rigurosamente evaluada en ocho ensayos clínicos. Es un procedimiento independiente del tamaño prostático, válido para cualquier próstata, altamente eficaz en el tratamiento de la retención urinaria. Se ha comunicado que la enucleación prostática con láser de Holmio es duradera hasta seis años. Se quita más tejido con la HOLEP y con la PVP y esto suscita una preocupación en cuanto a la duración a largo plazo del resultado de la PVP, de la que no existen datos comparables. El aumento de la experiencia con HolEP en todo el mundo y el desarrollo de láseres más rápidos en la ablación de tejidos y con otros usos urológicos (Ej tulio) puede amenazar la supervivencia de la PVP con láser de luz verde.

Palabras clave: Prostatectomía láser. Fotovaporización. Próstata. PVP. Holep. Láser.

\section{INTRODUCTION}

Laser surgery for benign prostatic hyperplasia (BPH) has become more widespread over the last 5 years, thanks to the marketing of the Greenlight laser. The aim of this review is to provide an evidence-based update on laser surgery for BPH with a focus on comparing Greenlight Photoselective Vaporisation of the Prostate (PVP) to Holmium Laser Enucleation of the Prostate (HoLEP).

Laser prostatectomy is a frequently used generic term that includes all laser techniques for the surgical relief of bladder outlet obstruction due to $\mathrm{BPH}$. It is more useful to consider the currently available lasers and laser techniques for BPH separately, as these can differ significantly.

\section{Current Lasers for BPH Surgery}

There are 3 wavelengths in current use:

1) Holmium:YAG (wavelength $=2140 \mathrm{~nm}$ )

2) KTP (The Greenlight laser $=532 \mathrm{~nm}$ )

3) Thulium (2140nm)

Although Thulium and Holmium have identical wavelengths their effects on prostate tissue differ. This occurs mainly due to a difference in their mode of emission (Holmium energy is emitted in a pulsed mode whereas Thulium is continuously emitted). This results in more rapid vaporisation with thulium and its ability to cut through prostate tissue like a hot knife through butter, but with more tissue charring compared to Holmium. The thulium laser is best suited to the techniques of ablation/vaporisation and resection (see below), but is not particularly well suited to enucleation. Thulium appears to vaporise tissue more rapidly than the Greenlight laser (personal experience). Holmium is the most effective laser currently for enucleation but it is slower than thulium at ablation and resection (personal experience). A laser's wavelength determines how its energy is absorbed by certain substances. Holmium and Thulium are both strongly absorbed by water and are therefore safe to use in an endoscopic environment through an end-firing fibre. Any energy not aimed directly onto the prostate is dissipated over a very short distance by the irrigating fluid. This means that the bladder is not exposed to any risk of laser injury when an end firing fibre is used in the prostatic urethra. On the contrary, the Greenlight laser, is poorly absorbed by water but is strongly absorbed by haemoglobin. If the Greenlight laser is used through an end firing fibre and directed up through the bladder neck it could penetrate through the irrigating fluid and damage the posterior bladder wall. This limits its use to ablation with a side-firing fibre only.

The holmium laser is very effective in the treatment of urinary calculi, but neither Greenlight or Thulium are effective. Holmium can be safely used to ablate small superficial transitional cell carcinomas (TCC) in the upper and lower urinary tracts. Thulium remains unproven for the treatment of TCC and Greenlight cannot be used for TCC.

\section{Current Laser Techniques}

There are 3 main types of laser technique. Not all of the lasers outlined above can be used for all the laser techniques (Table I).

\section{1) Ablation or vaporisation}

All the lasers mentioned above can be used to perform ablation or vaporisation of the prostate. In this technique the laser beam is directed sideways onto the prostate tissue by the use of a side-firing fibre, and a channel is burnt through the prostate. This is the most basic laser technique and is easy to learn, but with the currently available lasers, is a slow tedious procedure that with the greenlight laser only removes around 0.5 grams of tissue/minute (1). Other disadvantages of laser ablation include: the lack of any tissue for histology, the use of expensive single use sidefiring fibres, a reoperation rate of $15 \%$ at 7 years (2), and operator dependence (there is no uniformly used method of judging when to stop ablating). Vaporisation is the only BPH technique that can be performed with the Greenlight laser.

\section{2) Resection or vaporesection}

In addition to ablation/vaporisation, Holmium and Thulium can both be used to resect prostate tissue (3, 4). Laser resection evolved as a method of removing prostate tissue more efficiently than is possible with laser ablation. In this technique an end-firing fibre is used to perform bilateral bladder neck incisions and the median lobe of the prostate is enucleated. Next, the lateral lobes are resected in small fragments which are subsequently irrigated from the bladder. This is the laser version of TURP. Although faster then ablation it is not as efficient at removing tissue as enucleation and is unsuitable for very large prostates (5).

\section{3) Enucleation}

During Holmium laser resection of the prostate (HoLRP) it became obvious that the surgical plane between 
prostate adenoma and capsule could be entered with the holmium laser fibre and that each prostatic lobe could be peeled from the capsule in its entirety whilst maintaining excellent haemostasis. With the development of a suitable tissue morcellator HoLEP, a truly novel and highly efficient surgical intervention for BPH, became feasible. Laser enucleation is the most technically advanced form of laser prostate surgery and also the most rigorously investigated to date. It is the endoscopic equivalent of simple open prostatectomy. Once the correct plane is entered the lobes can be almost bluntly pushed off the capsule by the holmium energy. The perceived learning curve has been seen as a disadvantage but there is evidence to suggest that HoLEP can be safely and effectively taught (6-8).

Thulium can be used to enucleate but is more difficult for several reasons:

- A stream of bubbles emanates from the end of the thulium fibre which may interfere with the view of the surgical plane.

- The thulium laser cuts and chars tissue, rather than pushing the lobes bluntly from the capsule. This makes it difficult to remain in the correct plane.

\section{PVP versus HoLEP - A Review of the Evidence}

\section{Randomised trials}

\section{PVP}

There is only a single published randomised trial for PVP, comparing PVP to TURP (9). This paper is difficult to interpret as the trial had not concluded at the time of its publication, and only 44 of 120 patients had been evaluated at 12 months. The definitive results are awaited with interest.

\section{HoLEP}

There are 8 published randomised trials comparing HoLEP to: TURP (10-14), transurethral vapour resection (TUVRP) (14), bipolar enucleation (15), open prostatectomy $(16,17)$ and holmium bladder neck incision (HoBNI) (18).

The 4 HoLEP versus TURP trials report significantly less blood loss, catheter time, need for irrigation, nursing contact, and shorter hospital stay for HoLEP. The HoLEP operating times are consistently longer than for TURP but more tissue is removed with HoLEP. No TUR syndrome has ever been reported with HoLEP. Subjective and objective measures of success are at least equivalent to TURP. HoLEP is the first transurethral procedure to show improved urodynamic outcomes compared to TURP: Tan et al reported significantly greater urodynamic relief of bladder outlet with HoLEP at 6 months (10), although this was not reported in another trial (19).

In the randomised trial comparing HoLEP to TUVRP, HoLEP resulted in significantly less blood loss, less need for irrigation, less nursing time and shorter hospital stay (14).

Neill et al reported that enucleation was feasible using a Gyrus bipolar radiofrequency device but that it resulted in significantly longer operating time, need for irrigation and recovery room time than HoLEP (15). Outcomes at $1,3,6$ and 12 months were equivalent.

There are two randomised trials comparing HoLEP to open prostatectomy for large prostates $(16,17)$. Both report significantly longer operating time for HoLEP, but significantly less blood loss, shorter catheter and hospital times, and equivalent improvements in symptom and quality of life scores, maximal flow rates and post void residual volumes at 18 month (16) and 2 year (17) follow up.

Aho et al reported that HoLEP and HoBNI were feasible as day stay procedures for patients with glands less than 40 grams, and that HoLEP resulted in superior relief of bladder outlet obstruction particularly in those with prostates larger than 30 grams (18).

\section{Perioperative management}

As both the holmium and Greenlight lasers provide excellent haemostasis, catheter times, hospital stays and the infrequent need for irrigation are similar in reported HoLEP and PVP series. Both can be performed as day surgery procedures $(18,20,21,22)$

\section{Subjective and objective measures of success}

There are no randomised trials comparing PVP and HoLEP. There are however a number of published case series for PVP (21-29). A comparison of the results of these

TABLE I. APPLICATIONS OF THE CURRENT UROLOGICAL LASERS.

\begin{tabular}{|c|c|c|c|c|c|}
\hline & Ablation for BPH & Resection for BPH & Enucleation for BPH & TCC ablation & Stones \\
\hline Holmium & Yes & Yes & Yes & Yes & Yes \\
\hline Greenlight & Yes & No & No & No & No \\
\hline Thulium & Yes & Yes & Difficult & Unproven & No \\
\hline
\end{tabular}


and similar sized HoLEP series (Table II) suggests that both procedures result in similar symptom and quality of life improvements, but there is greater improvement in maximal flow rate and post void residual volume with HoLEP.

\section{Complications}

PVP

The most common complications of PVP are persistent dysuria (mean duration 2 months), and haematuria (mean duration 1 month). These have been reported in up to $30 \%$ and $18 \%$ respectively (27). Rates of other reported complications include: ureteric injury $1.8 \%(28)$, recatheterisation $0-15.4 \%(29)$, urinary incontinence $0-6.5 \%(22)$, urethral stricture $0.7-4 \%(22,25)$ and bladder neck contracture $0.9-3.5 \%(25,26)$. TUR syndrome does not occur with PVP.

\section{HoLEP}

Shah et al report a prospective case study of the complications of HoLEP in 280 patients (30). Despite including their learning curve, the overall complication rates

\section{TABLE II.COMPARISON OF SUBJECTIVE AND OBJECTIVE MEASURES OF SUCCESS: PVP AND HOLEP.}

\begin{tabular}{|c|c|c|c|c|c|c|c|}
\hline Procedure & Author & Number & $\begin{array}{l}\text { Mean Pre-op } \\
\text { TRUS Volume }\end{array}$ & $\begin{array}{c}\text { Mean \% } \\
\text { change in IPSS }\end{array}$ & $\begin{array}{c}\text { Mean \% } \\
\text { change in QOL } \\
\text { score }\end{array}$ & $\begin{array}{c}\text { Mean \% } \\
\text { Change in } \\
\text { Qmax }\end{array}$ & $\begin{array}{c}\text { Mean \% } \\
\text { Change in } \\
\text { PVR }\end{array}$ \\
\hline $\begin{array}{c}\text { HoLEP } \\
\text { 80-100W }\end{array}$ & $\begin{array}{l}\text { Kuntz et al } \\
2004 \text { (12) }\end{array}$ & 100 & $53.5+20$ & 92 at $12 / 12$ & & $\begin{array}{ll}412 & 6 / 12 \\
469 & 12 / 12\end{array}$ & $\begin{array}{ll}98 & 6 / 12 \\
98 & 12 / 12\end{array}$ \\
\hline $\begin{array}{c}\text { HoLEP } \\
80-100 \mathrm{~W}\end{array}$ & $\begin{array}{l}\text { Gupta et al } \\
2006 \text { (14) }\end{array}$ & 50 & $57.9+5.1$ & $\begin{array}{l}78 \text { at } 6 / 12 \\
78 \text { at } 12 / 12\end{array}$ & & $\begin{array}{ll}344 & 6 / 12 \\
388 & 12 / 12\end{array}$ & $\begin{array}{ll}82 & 6 / 12 \\
82 & 12 / 12\end{array}$ \\
\hline $\begin{array}{l}\text { HoLEP } \\
70 W\end{array}$ & $\begin{array}{l}\text { Montorsi et al } \\
2004 \text { (13) }\end{array}$ & 52 & $70.3+36.7$ & $\begin{array}{l}82 \text { at } 6 / 12 \\
81 \text { at } 12 / 12\end{array}$ & $\begin{array}{l}78 \text { at } 6 / 12 \\
70 \text { at } 12 / 12\end{array}$ & $\begin{array}{ll}182 & 6 / 12 \\
206 & 12 / 12\end{array}$ & \\
\hline $\begin{array}{c}\text { HoLEP } \\
\text { 80-100W }\end{array}$ & $\begin{array}{c}\text { Kuntz et al } \\
2002(16)+()\end{array}$ & 60 & $114.6+21.6$ & $\begin{array}{l}89 \text { at } 6 / 12 \\
90 \text { at } 12 / 12\end{array}$ & & $\begin{array}{ll}687 & 6 / 12 \\
621 & 12 / 12\end{array}$ & $\begin{array}{ll}98 & 6 / 12 \\
98 & 12 / 12\end{array}$ \\
\hline $\begin{array}{c}\text { HoLEP } \\
\text { 80-100W } \\
\end{array}$ & $\begin{array}{l}\text { Elzayat et al } \\
2006(36)\end{array}$ & 225 & $126+45.1$ & $\begin{array}{l}81 \text { at } 6 / 12 \\
79 \text { at } 12 / 12\end{array}$ & $\begin{array}{l}78 \text { at } 6 / 12 \\
78 \text { at } 12 / 12 \\
\end{array}$ & $\begin{array}{rr}226 & 6 / 12 \\
224 & 12 / 12 \\
\end{array}$ & $\begin{array}{ll}91 & 6 / 12 \\
91 & 12 / 12 \\
\end{array}$ \\
\hline $\begin{array}{l}\text { PVP } \\
80 \mathrm{~W}\end{array}$ & $\begin{array}{l}\text { Reich et al } \\
2005 \text { (23) }\end{array}$ & 66 & $49+30$ & $\begin{array}{l}66 \text { at } 6 / 12 \\
68 \text { at } 12 / 12\end{array}$ & & $\begin{array}{rr}187 & 6 / 12 \\
222 & 12 / 12 \\
\end{array}$ & $\begin{array}{cc}81 & 6 / 12 \\
83 & 12 / 12 \\
\end{array}$ \\
\hline $\begin{array}{l}\text { PVP } \\
80 \mathrm{~W}\end{array}$ & $\begin{array}{l}\text { Sarica et al } \\
2005(24)\end{array}$ & 240 & 52.1 & $\begin{array}{l}77 \text { at } 6 / 12 \\
84 \text { at } 12 / 12\end{array}$ & 87 at $6 / 12$ & $\begin{array}{ll}230 & 6 / 12 \\
253 & 12 / 12\end{array}$ & $\begin{array}{cc}64 & 6 / 12 \\
89 & 12 / 12 \\
\end{array}$ \\
\hline $\begin{array}{l}\text { PVP } \\
80 \mathrm{~W}\end{array}$ & $\begin{array}{c}\text { Bachmann et al } \\
2005 \text { (25) }\end{array}$ & 108 & $52.2+24.3$ & $\begin{array}{l}66 \text { at } 6 / 12 \\
62 \text { at } 12 / 12\end{array}$ & $\begin{array}{l}67 \text { at } 6 / 12 \\
69 \text { at } 12 / 12\end{array}$ & $\begin{array}{ll}201 & 6 / 12 \\
252 & 12 / 12\end{array}$ & $\begin{array}{ll}85 & 6 / 12 \\
77 & 12 / 12\end{array}$ \\
\hline $\begin{array}{r}\text { PVP } \\
80 \mathrm{~W} \\
\end{array}$ & $\begin{array}{c}\text { Te et al } \\
2004(22)\end{array}$ & 139 & $67.7+8.7$ & $\begin{array}{l}79 \text { at } 6 / 12 \\
82 \text { at } 12 / 12\end{array}$ & $\begin{array}{l}72 \text { at } 6 / 12 \\
77 \text { at } 12 / 12 \\
\end{array}$ & $\begin{array}{ll}179 & 6 / 12 \\
190 & 12 / 12 \\
\end{array}$ & $\begin{array}{ll}77 & 6 / 12 \\
78 & 12 / 12 \\
\end{array}$ \\
\hline $\begin{array}{l}\text { PVP } \\
80 W\end{array}$ & $\begin{array}{l}\text { Sandhu et al } \\
2004(26)\end{array}$ & 64 & $101+40$ & $\begin{array}{l}62 \text { at } 6 / 12 \\
64 \text { at } 12 / 12\end{array}$ & & $\begin{array}{ll}153 & 6 / 12 \\
139 & 12 / 12\end{array}$ & $\begin{array}{ll}65 & 6 / 12 \\
42 & 12 / 12\end{array}$ \\
\hline
\end{tabular}


are low. Capsular perforation occurred in $9.6 \%$, superficial bladder mucosal injury in $3.9 \%$, and ureteric orifice injury in $2.1 \%$. Blood transfusion was given in $1.4 \%$, and cystoscopy and clot evacuation was performed in $0.7 \%$. There was no TUR syndrome. Recatheterisation was required in $3.9 \%$. The commonest complication was transient urinary incontinence (10.7\%) which resolved in all but two $(0.7 \%)$. Meatal/submeatal stenosis occurred in $2.5 \%$, urethral stricture in $2.1 \%$ and bladder neck contracture in $0.35 \%$.

\section{Sexual Function}

\section{PVP}

In a study of sexual function and PVP the International Index of Erectile function (IIEF) was completed by 45 patients just before and 6 months after surgery (31). All IIEF domains improved after PVP. Retrograde ejaculation is reported in up to $36 \%$ after PVP. (22)

\section{HoLEP}

The IIEF-EF score was also used by Briganti et al to evaluate the effect of HoLEP and TURP on sexual function as part of a randomised trial (32). TURP and HoLEP both significantly lowered the orgasmic function domain to a similar degree due to retrograde ejaculation. Marginal non significant improvements in erectile function were reported at 12 and 24 months by both groups.
Meng et al evaluated sexual function in 108 HoLEP patients using the Danish Prostate Symptom Score Sexual Function Questionnaire. (33) Satisfaction with libido, erections and sex life was unaltered at 6 months after HoLEP. Early morning erections were reported by $45 \%$ preoperatively and $62 \% 6$ months later $(p<0.01)$. Retrograde ejaculation occurred in $70 \%$.

\section{Volume Reduction}

When considering transrectal ultrasound (TRUS) measured volume before and after surgery, it is clear that a significantly greater percentage of tissue is removed by HoLEP than PVP. (Table III). PSA can be used as a surrogate measure of prostate volume reduction (34). The significantly greater decrease in PSA after HoLEP compared to PVP suggests that adenoma removal is more complete with HoLEP (Table III).

\section{Durability}

PVP

Interpretable long term data on PVP outcomes are lacking. Malek et al report on follow-up to 5 years but only $51 \%$ of the original 94 patients were evaluable at 2 years, $34 \%$ at 3 years and $15 \%$ at 5 years (37). Most other PVP series provide follow-up data to 12 months only. Rajbabu

TABLE III. VOLUME REDUCTION FROM TRUS AND PSA: PVP AND HOLEP.

\begin{tabular}{|c|c|c|c|c|c|}
\hline Procedure & Author & Number & $\begin{array}{l}\text { When measured } \\
\text { post -operatively }\end{array}$ & $\begin{array}{c}\text { Mean \% } \\
\text { Reduction in } \\
\text { TRUS volume }\end{array}$ & $\begin{array}{c}\text { Mean \% } \\
\text { Reduction in PSA }\end{array}$ \\
\hline HoLEP & Tinmouth et al 2005 (34) & 509 & Not stated & $76 \%$ & $84 \%$ \\
\hline HoLEP & Matlaga et al 2006 (35) & $\begin{array}{l}20 \text { for TRUS } \\
48 \text { for PSA }\end{array}$ & Not stated & $82 \%$ & $90 \%$ \\
\hline HoLEP & Elzayad et al 2006 (36) & 225 & 6 months & & $90 \%$ \\
\hline PVP & Rajbabu et al 2007 (28) & 33 & 6 months & & $50 \%$ \\
\hline PVP & Rajbabu et al 2007 (28) & 38 & 3 months & $45 \%$ & \\
\hline PVP & Sandhu et al 2004 (26) & 64 & 12 months & $44 \%$ & \\
\hline PVP & Te et al 2004 (22) & 139 & 12 months & $37 \%$ & \\
\hline PVP & Sulser et al 2004 (29) & 65 & 12 months & $30 \%$ & $34.7 \%$ \\
\hline PVP & Volkan et al 2005 (27) & 186 & 12 months & & $42 \%$ \\
\hline PVP & Malek et al 2005 (37) & 94 & 12 months & & $32 \%$ \\
\hline
\end{tabular}




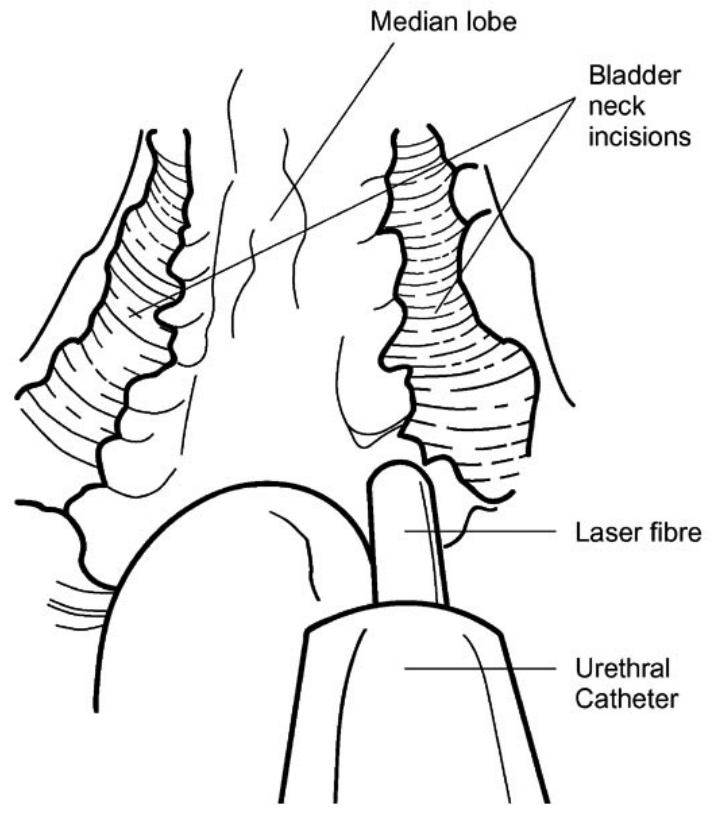

FIGURE 1. Bladder neck incisions.

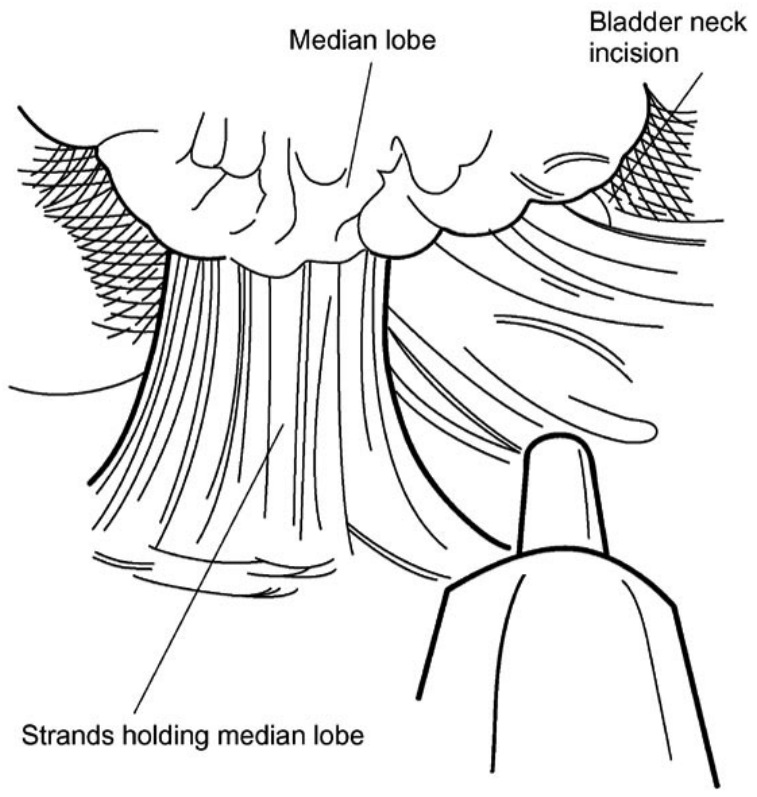

FIGURE 2. Enucleation of the median lobe of the prostate towards the bladder neck.

Ahyai et al have evaluated $72 \%$ of their original patients at 3 years in their randomised trial of HoLEP versus TURP (39). The reoperation rate for BPH in the HoLEP group was $1 \%$ compared to 0 in the TURP group. Most subjective and objective outcome measures were similar between TURP and HoLEP groups at 3 years, although post void residual was significantly less in the HoLEP group (not at a clinically relevant level). Vavassori et al report a reoperation rate for $\mathrm{BPH}$ for HoLEP of $2.7 \%$ at 3 years (40). Five

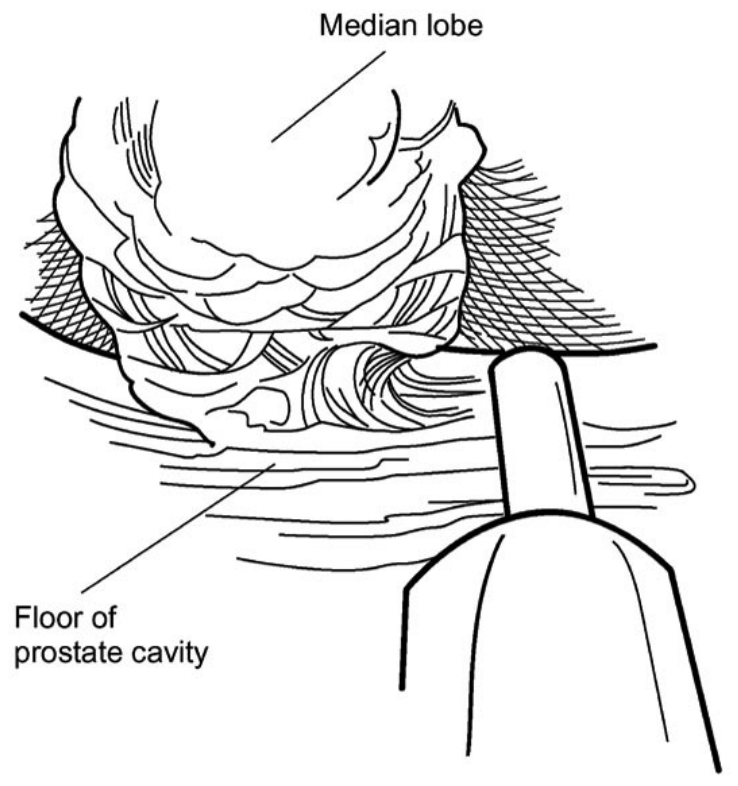

FIGURE 3. Detachment of the median lobe at the bladder neck.

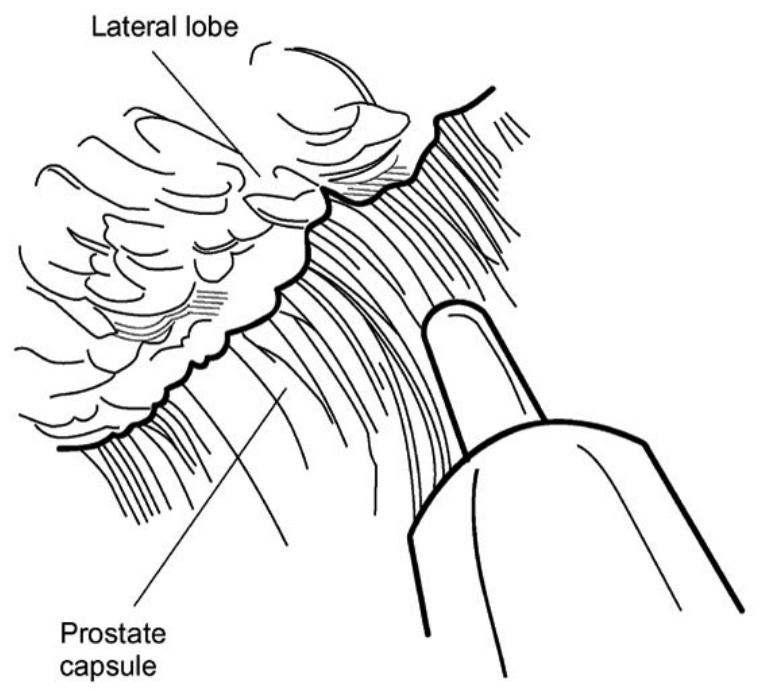

FIGURE 4. Enucleating the left lateral lobe of the prostate from below. 


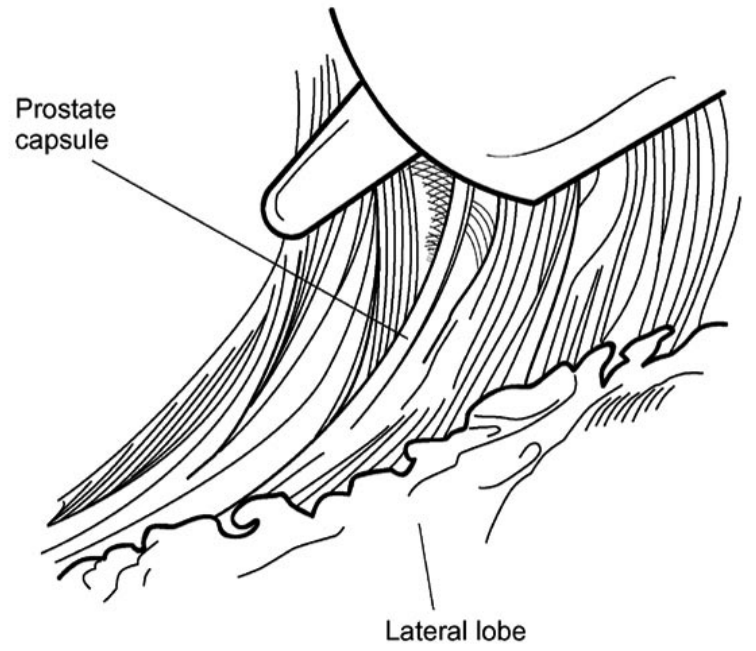

FIGURE 5. Dropping the left lateral lobe of the prostate down from above.

year data from their randomised trial of HoLEP versus open prostatectomy trial for prostates greater than 100 grams is reported by Kuntz et al (41). An impressive $62 \%$ of the original patients were evaluated at 5 years. There were no differences between groups in symptom scores, maximum flow rates, post void residual volumes or complications at 5 years. No patients in either group required a reoperation for BPH up to 5 years. Gilling et al report on 6 year follow up for HoLEP with $54 \%$ of their original patients evalua-

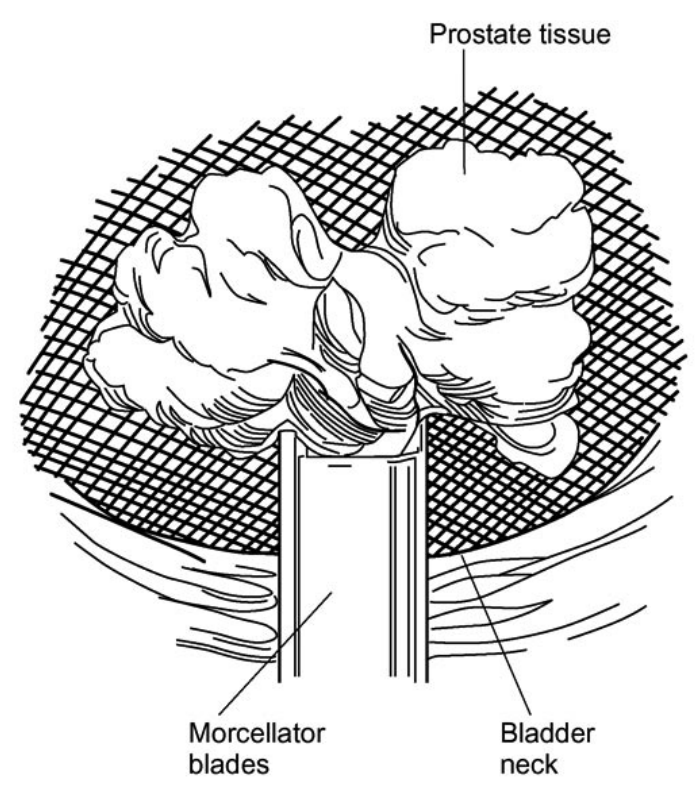

FIGURE 7. Morcellation of prostate tissue within the bladder.

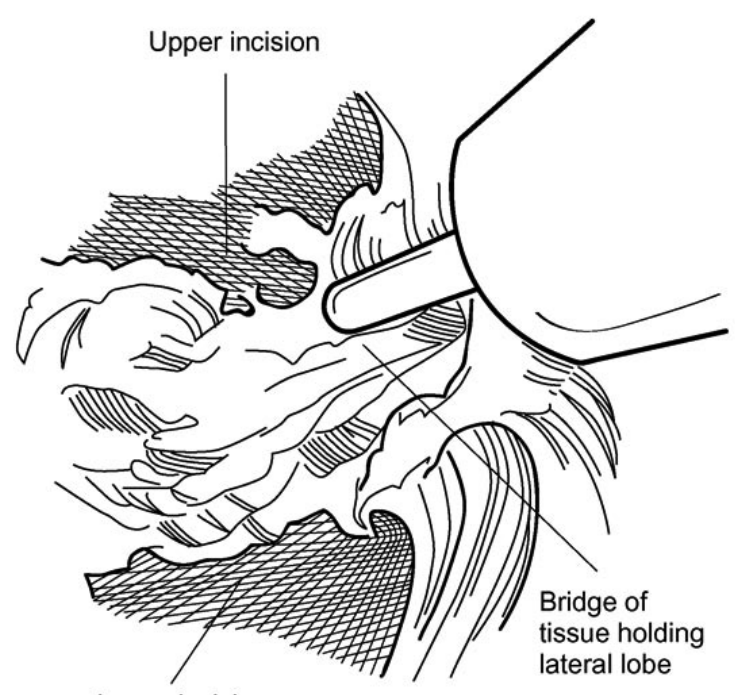

FIGURE 6. Detaching the left lateral lobe at the bladder neck.

ble (42). Reoperation rate for BPH was $1.4 \%$, and $92 \%$ were satisfied or extremely satisfied with their outcomes at 6 years.

\section{Large prostates}

PVP

PVP has been evaluated for large prostates in 2 centres $(28,26)$. Both reported short catheter times and hospital stays, and few perioperative complications. Interestingly, both also reported improvements in clinical outcomes at 1 year that are less impressive than for PVP series with smaller prostates: Improvements in IPSS, Qmax and PVR reported by Rajbabu et al were $72 \%, 124 \%$, and $63 \%$; and by Sandhu et al were $64 \%, 139 \%$ and $42 \%$ respectively. These results can be compared with those of other PVP series in Table 2, and suggest that PVP results might not be size independent. Mean TRUS volume reduction in the study by Rajbabu was $45 \%$ indicating that a significant volume of adenoma remained after PVP. This raises a concern that durability may be an issue for PVP, particularly in large glands. Longer term data for large prostates is awaited.

\section{HoLEP}

Several authors have reported on the outcomes for HoLEP for large glands $(35,36,41)$. All agree it is safe and effective and volume reduction range from $69-82 \%$ (36, 35 ). As mentioned previously, Kuntz et al reported clinical outcomes at 5 years for prostates $>100$ grams to be equivalent to open prostatectomy in a randomised trial, and no reoperations for $\mathrm{BPH}$ were required (41).

All 3 papers analysing the effect of prostate size on HoLEP suggest that HoLEP outcomes are independent of prostate size (43-45). 


\section{Retention}

PVP

Ruzsat et al compared PVP performed for urinary retention (UR) and for lower urinary tract symptoms (LUTS) (38). There were no significant differences in length of stay (UR $=5.5$ days, LUTS $=5.3$ days), catheter time (UR $=1.7$ days, LUTS $=1.8$ days), the proportion of patients discharged with catheters (UR $=10 \%$, LUTS $=8.8 \%$ ), or complication rates. Only $19 \%$ of the original patients were evaluated at 2 years, but within a 2 year period the reintervention rate for recurrent obstructive $\mathrm{BPH}$ was $2.7 \%$. Functional results up to 2 years were similar between groups. Although 10\% in the UR group were discharged with catheters, it is not stated how many (if any) of these subsequently had a successful trial without catheter.

\section{HoLEP}

Two papers evaluate the use of HoLEP for patients in urinary retention pre-operatively. Elzayat et al report on 169 patients with mean pre-operative TRUS prostate volume of $101 \mathrm{cc}(46)$. Mean catheter time and hospital stay were 1.6 and 1.7 days respectively. Three (1.8\%) failed to void postoperatively. Peterson et al studied 154 patients with a mean pre-operative TRUS volume of $107.1 \mathrm{cc}$ and a mean prostate volume reduction after HoLEP of $76 \%$ (47). Mean catheter time and hospital stay were 22.5 and 33.7 hours respectively. All patients were able to void post-operatively and remained catheter free at follow-up to 1 year, although only $22 \%$ of the original patients were evaluated at 1 year.

\section{CONCLUSION}

PVP and HoLEP are very different laser techniques for the treatment of obstructive BPH. As an ablative technique PVP is not a new concept and is an identical technique to HoLAP and thulium vaporisation. An important difference between the Greenlight laser and holmium and thulium is that it's only urological application is prostate ablation. HoLEP is the most advanced laser technique currently available. In contrast to PVP (for which there is only a single, yet to be completed, published randomised trial), it has been rigorously evaluated in 8 randomised trials. It is a size independent procedure suitable for any prostate, and highly effective at treating urinary retention. HoLEP has recently been reported to be durable to periods up to 6 years. More tissue is removed with HoLEP than PVP, and this raises concerns regarding the long term durability of PVP for which there is no comparable data.

The increase in HoLEP expertise world-wide and the development of lasers that are faster at ablating tissue and have other urological uses (eg thulium) may threaten the longevity of Greenlight PVP.

\section{REFERENCES AND RECOMENDED READINGS}

1. KUNTZ, R.: "Current role of lasers in the treatment of benign prostatic hyperplasia (BPH)". Eur. Urol., 49: 961,2006
2. TAN, A.; GILLING, P.; KENNETT, K. y cols.: "Longterm results of high-power holmium laser vaporisation (ablation) of the prostate". BJU Int., 92: 707, 2003.

3. GILLING, P.; CASS, C.; CRESWELL, M. y cols.: "Holmium laser resection of the prostate: Preliminary results of a new method for the treatment of benign prostatic hyperplasia". Urology, 47: 48, 1996.

4. BACH, T.; HERRMANN, T.; GANZER, R. y cols.: "Revolix vaporesection of the prostate: initial results of 54 patients with a 1-year follow-up". World J. Urol., 25: 257,2007

5. WESTENBERG, A.; GILLING, P.; KENNETT, K. y cols.: "Holmium laser resection of the prostate versus transurethral resection of the prostate: results of a randomised trial with a 4-year minimum long-term followup". J. Urol., 172: 616, 2004.

6. EL-HAKIM, A.; ELHILALI, M.: "Holmium laser enucleation of the prostate can be taught: The first learning experience". BJU Int., 90: 863, 2002.

7. SHAH, H.; MAHAJAN, A.; SODHA, H. y cols.: "Prospective evaluation of the learning curve for holmium laser enucleation of the prostate". J. Urol., 177: 1468.

8. SEKI, N.; MOCHIDA, O.; KINUKAWA, N. y cols.: "Holmium laser enucleation for prostatic adenoma: Analysis of learning curve over the course of 70 consecutive cases". J. Urol., 170: 1847, 2003.

9. BOUCHIER-HAYES, D.; ANDERSON, P.; VAN APPLEDORN, S. y cols.: "KTP Laser versus Transurethral Resection: Early Results of a Randomised Trial". J. Endourol., 20: 580, 2006.

10. TAN, A.; GILLING, P.; KENNETT, K. y cols.: "A randomised trial comparing holmium laser enucleation of the prostate with transurethral resection of the prostate for the treatment of bladder outlet obstruction secondary to benign prostatic hyperplasia in large glands (40 to 200 grams)". J. Urol., 170: 1270, 2003.

11. WILSON, L.; GILLING, P.; WILLIAMS, A. y cols.: "A randomised trial comparing holmium laser enucleation versus transurethral resection in the treatment of prostates larger than 40 grams: Results at 2 years". M. Eur. Urol., 50: 569, 2006.

12. KUNTZ, R.; AHYAI, S.; LEHRICH, K. y cols.: "Transurethral holmium laser enucleation of the prostate versus transurethral electrocautery resection of the prostate: A randomised prospective trial in 200 patients". J. Urol., 172: 1012, 2004.

13. MONTORSI, F.; NASPRO, R.; SALONIA, A. y cols.: "Holmium laser enucleation versus transurethral resection of the prostate: Results from a 2-center, prospective, randomised trial in patients with obstructive benign prostatic hyperplasia”. J. Urol., 172: 1926, 2004.

14. GUPTA, N.; SIVARAMA, K.; KUMAR, R. y cols.: "Comparison of standard transurethral resection, transurethral vapour resection and holmium laser enucleation of the prostate for managing benign prostatic hyperplasia of > $40 \mathrm{~g}$ ". BJU Int., 97: 85, 2006.

15. NEILL, M.; GILLING, P.; KENNETT, K. y cols.: "Randomised trial comparing holmium laser enucleation of prostate with palsmakinetic enucleation of prostate for treatment of benign prostatic hyperplasia”. Urology, 68: 1020, 2006. 
16. KUNTZ, R.; LEHRICH, K.: "Transurethral holmium laser enucleation versus transvesical open enucleation for prostate adenoma greater than $100 \mathrm{gm}$ : A randomised prospective trial of 120 patients". J. Urol., 168: 1465, 2002.

17. NASPRO, R.; SUARDI, N.; SALONIA, A. y cols.: "Holmium laser enucleation of the prostate versus open prostatectomy for prostates > 70g: 24-month followup". Eur. Urol., 50: 563, 2006.

18. AHO, T.; GILLING, P.; KENNETT, K. y cols.: "Holmium laser bladder neck incision versus holmium enucleation of the prostate as outpatient procedures for prostates less than 40 grams: A randomised trial". J. Urol., 175: 210, 2005.

19. RIGATTI, L.; NASPRO, R.; SALONIA, A. y cols.: "Urodynamics after TURP and HoLEP in urodynamically obstructed patients: Are there any differences at 1 year of follow-up?". Urology, 67: 1193, 2006.

20. LARNER, T.; AGARWAL, D.; COSTELLO, A.: "Daycase holmium laser enucleation of the prostate for gland volumes of < 60ml: Early experience". BJU Int., 91: 61, 2003.

21. MALEK, R.; KUNTZMAN, R.; BARRETT, D.: "High power potassium-titanyl-phosphate laser vaporisation prostatectomy". J. Urol., 163: 1730, 2000.

22. TE, A.: MALLOY, T.; STEIN, B. y cols.: "Photoselective vaporisation of the prostate for the treatment of benign prostatic hyperplasia: 12-month results from the first United States multicentre prospective trial". J. Urol., 172: 1404, 2004.

23. REICH, O.; BACHMANN, A.; SIEBELS, M. y cols.: "High power (80W) potassium-titanyl-phosphate laser vaporisation of the prostate in 66 high risk patients". J. Urol., 173: 158, 2005.

24. SARICA, K.; ALKAN, E.; LULECI, H. y cols.: "Photoselective vaporisation of the enlarged prostate with KTP laser: Long-term results in 240 patients”. J. Endourol., 19: 1199, 2005.

25. BACHMANN, A.; RUSZAT, R.; WYLER, S. y cols.: "Photoselective vaporisation of the prostate: The Basel experience after 108 procedures". Eur. Urol., 47: 798, 2005.

26. SANDHU, J.N.G.C.; VANDERBRINK, B.; EGAN, C. y cols.: "High power potassium-titanyl-phosphate photoselective laser vaporisation of prostate for treatment of benign prostatic hyperplasia in men with large prostates". Urology, 64: 1155, 2004.

27. VOLKAN, T.; IHSAN YILMAZ, O.; EMIN, O. y cols.: "Short term outcomes of high power $(80 \mathrm{~W})$ potassiumtitanyl-phosphate laser vaporisation of the prostate". Eur. Urol., 48: 608, 2005.

28. RAJBABU, K.; CHANDRASEKARA, S.; BARBER, N. y cols.: "Photoselective vaporisation of the prostate with the potassium-titanyl-phosphate laser in men with prostates of > 100ml". BJU Int., 100: 593, 2007.

29. SULSER, T.; REICH, O.; WYLER, S. y cols.: "Photoselective KTP laser vaporisation of the prostate: First experience with 65 procedures". J. Endourol., 18: 976, 2004.

30. SHAH, H.; MAHAJAN, A.; HEGDE, S. y cols.: "Perioperative complications of holmium laser enucleation of the prostate: Experience in the first 280 patients, and a review of the literature". BJU Int., 100: 94, 2007.

31. PAICK, J.; UM, J.; KIM, S. y cols.: "Influence of high power FTP photoselective vaporisation of the prostate on erectile function: A short-term follow-up study". J. Sex. Med., 4: 1701, 2007.

32. BRIGANTI, A.; NASPRO, R.; GALLINA, A. y cols.: "Impact on sexual function of holmium laser enucleation versus transurethral resection of the prostate: $\mathrm{Re}$ sults of a prospective 2-center, randomised trial". J. Urol., 175: 1817, 2006.

33. MENG, F.; GAO, B.; FU, Q. y cols.: "Change of sexual function in patients before and after Ho: YAG laser enucleation of the prostate". J. Androl., 28: 259, 2007.

34. TINMOUTH, W.; HABIB, E.; KIM, S. y cols.: "Change in serum prostate specific antigen concentration after holmium laser enucleation of the prostate: A marker for completeness of adenoma resection?". J. Endourol., 19: $550,2005$.

35. MATLAGA, B.; KIM, S.; KUO, R. y cols.: "Holmium laser enucleation of the prostate for prostates $>125 \mathrm{ml}$ ". BJU Int., 97: 81.

36. ELZAYAT, E.; ELHILALI, M.: "Holmium laser enucleation of the prostate: The endourologic alternative to open prostatectomy”. Eur. Urol., 49: 87, 2006.

37. MALEK, R.; KUNTZMAN, R.; BARRETT, D.: "Selective KTP laser vaporisation of the benign obstructive prostate: Observations on long-term outcomes". J. Urol., 174: 1344, 2005.

38. RUSZAT, R.; WYLER, S.; SEIFERT, H. y cols.: "Photoselective vaporisation of the prostate: Subgroup analysis of men with refractory urinary retention". Eur. Urol., 50: 1040, 2006.

39. AHYAI, S.; LEHRICH, K.; KUNTZ, R.: "Holmium laser enucleation versus transurethral resection of the prostate: 3-year follow-up results of a randomised clinical trial”. Eur. Urol., 52: 1456, 2007.

40. VAVASSORI, I.; VALENTI, S.; NASPRO, R. y cols.: "Three-year outcome following holmium laser enucleation of the prostate combined with mechanical morcellation in 330 consecutive patients". Eur. Urol., 53: 599, 2008.

41. KUNTZ, R.; LEHRICH, K.; AHYAI, S.: "Holmium laser enucleation of the prostate versus open prostatectomy for prostates greater than 100 grams: 5-year follow-up results of a randomised clinical trial". Eur. Urol., 53: 160, 2008.

42. GILLING, P.; AHO, T.; FRAMPTON, C. y cols.: "Holmium laser enucleation of the prostate: Results at 6 years". Eur. Urol., 2007.

43. SHAH, H.; SODHA, H.; KHARODAWALA, S. y cols.: "Influence of prostate size on the outcome of holmium laser enucleation of the prostate". BJU Int., 2008.

44. SEKI, N.; TATSUGAMI, K.; NAITO, S.: "Holmium laser enucleation of the prostate: Comparison of outcomes according to prostate size in 97 Japanese patients". J. Endourol., 21: 192, 2007.

45. KUNTZ, R.; LEHRICH, K.; AHYAI, S.: "Does perioperative outcome of transurethral holmium laser enucleation of the prostate depend on prostate size?". J. Endourol., 18: 183, 2004.

46. ELZAYAT, E.; HABIB, E.; ELHILALI, M.: "Holmium laser enucleation of prostate for patients in urinary retention". Urology, 66: 789, 2005.

47. PETERSON, M.; MATLAGA, B.; KIM, S. y cols.: "Holmium laser enucleation of the prostate for men with urinary retention”. J. Urol., 174: 998, 2005. 